\title{
INTERAKSI SOSIAL ANAK BERKEBUTUHAN KHUSUS DI SDN 4 KILENSARI
}

\author{
Amalia Risqi Puspitaningtyas ${ }^{1)}$ \\ 1) Universitas Abdurachman Saleh Situbondo \\ amaliarisqipuspitaningtyas@gmail.com
}

\begin{abstract}
ABSTRAK: Penelitian ini bertujuan untuk mendiskripsikan interaksi sosial siswa berkebutuhan khusus di lingkungan sekolah dasar. Penelitian ini menggunakan metode deskriptif kualitatif. Subjek dalam penelitain ini yaitu siswa berkebutuhan khusus yang ada di kelas 1 yaitu berjumlah 3 orang dengan kriteria sown syndrome, tuna rungu dan autis, penelitian ini dilaksanakan di lingkungan SDN 4 kilensari. Jenis pengumpulan data yang digunakan yaitu obesrvasi, wawancara serta studi dokumentasi. Hasil penelitian ini menunjukan bahwa siswa berkebutuhan khusus yang ada di kelas 1 dapat berinteraksi sosial dengan siswa reguler yang ada di lingkungan SDN 4 kilensari yang menjadi salah satu sekolah inklusi yang ada di kec.Panarukan. Interaksi sosial di dukung oleh guru kelas dan guru pendamping dengan memberikan stimulus pada anak berkebutuhan khusus agar dapat berinteraksi dengan anak siswa reguler dengan bermain dan membiasakan ketika masuk kelas untuk mengucapkan salam dan bersalaman.
\end{abstract}

Kata kunci : Interaksi Sosial, Anak Berkebutuhan Khusus

ABSTRACT: This study aims to describe the social interactions of students with special needs in the elementary school environment. This study used descriptive qualitative method. Subjects in this study are students with special needs in class 1, amounting to 3 people with criteria for sown syndrome, hearing impaired and autistic, this study was conducted in the 4 kilensari SDN environment. The types of data collection used are observation, interviews and documentation studies. The results of this study indicate that students with special needs in class 1 can interact socially with regular students in the 4 kilensari SDN environment which are one of the inclusive schools in Kec .ukan. Social interaction is supported by class teachers and accompanying teachers by providing stimulus to children with special needs in order to be able to interact with regular students by playing and getting used to entering class to say hello and shake hands.

Keywords: Social Interaction, Children with Special Needs.

\section{PENDAHULUAN}

Perkembangan sosial anak sekolah dasar di tandai dengan adanya perluasan hubungan, disamping dengan para anggota keluarga, juga dengan teman sebaya, sehingga ruang gerak hubungan sosialnya bertambah luas. Anak- anak mulai berminat terhadap kegiatan- kegiatan teman sebaya dan bertambah kuat keinginannya untuk diterima menjadi anggota kelompoknya. Karakteristik anak pada permulaan memasuki lingkungan sekolah, maka pada waktu itulah permulaan anak mengenal sekolah. Kemampuan anak untuk berinteraksi dan berprilaku yang dapat diterima secara sosial merupakan hal yang sangat penting bagi anak untuk hidup dalam suatu masyrakat. Soerjono (2009: 54) mengatakan interaksi soial merupakan kunci dari semua kehidupan sosial, karena tanpa interaksi sosial tak akan mungkin ada kehidupan bersama. Interaksi dilakukan antar individu dan antar kelompok secara sadar dengan menggunakan simbol - simbol yang didalamnya berisi tanda- tanda atau isyarat dan kata- kata. Anak yang pada mulanya belum saling mengenal antara satu sama lain, beberapa waktu kemudian sudah saling mengenal dalam ruang lingkup pergaulan sehari - hari di kelas dan sekolah. Anak 
berkebutuhan khusus memang sering kali dibedakan oleh masyarakat padahal anak berkebutuhan khusus memiliki hak yang sama seperti anak normal pada umumnya.

Anak berkebutuhan khusus membutuhkan bantuan untuk mengembangkan kemampuannya dalam berinteraksi dengan lingkungan. Selain orang tua, kebedaraan sosok guru di sekolah menduduki peran yang sangat penting terlebih pada sekolah inklusi yang merupakan satuan pendidikan yang diadakan oleh pemerintah sebagi perwujudan usaha membantu anak berkebutuhan khusus dalam bidang pendidikan melalui prinsip menerima semua bentuk siswa baik yang memiliki kebutuhan khusus maupun tidak untuk dapat melakukan pembelajran bersama- sama. Dalam pendangan pendidikan seorang anak yang memiliki berkebutuhan khusus, perbedaan sangat dihargai. Seorang anak berkebutuhan khusus masing- masing mempunyai sesuatu keunikan yang berbeda. Anak berkebutuhan khusus membutuhkan pendidikan adaptasi lingkungan agar apa yang mereka miliki dapat mengembangkan sendirinya serta dapat menimbulkan interaksi yang baik. Permasalahan yang dialami mengakibatkan anak yang memiliki kebutuhan khusus sulit melakukan aktivitas yang bersifat sosial terhadap orang lain di lingkungannya. anak berkebutuhan khusus lebih sering melakukan aktifitas sosial dan bermain sendiri. Anak berkebutuhan khusus lebih memilih untuk menyibukkan sendiri, pada umumnya lebih memilih berteman atau lebih suka bermain dengan benda- benda yang ada di sekitarnya. Kesadaran dalam berinteraksi masih kurang, sehingga menyebabkan anak berkebutuhan khusus belum memahami mimik wajah orang lain ataupun mengekespresikan perasaan dirinya sendiri.

Jika seorang anak mampu berinetraksi dengan baik terhadap lingkungan, perlahan anak akan merasa terbiasa berkerjasama. Salah pengkondisian lingkungan biasanya siswa berkebutuhan khusus sering terlibat konflik, persaingan karena ingin diperhatikan bahkan bisa sampai menarik diri dari pembelajaran. Guru juga bisa menggunakan teknik belajar yang cocok untuk membantu interaksi anak yang disesuaikan dengan kebutuhannya, seperti menggunakan metode kerja kelompok yang terbukti efektif dalam meningkatkan interaksi sosial siswa.

SDN 4 Kilensari Kab. Situbondo merupakan sekolah penyelenggara pendidikan inklusi yang menggabungkan siswa berkategori reguler dan siswa berkebutuhan khusus.Hal ini juga yang mengakibatkan keadaan gurunya ikut berbeda. Di SDN 4 kilensari pendamping khusus bagi siswa berkebutuhan khusus di dalam kelas, yaitu guru kelas (guru pengajar) dan guru pendamping khusus. Guru kelas mempunyai peran memberikan pelajaran kepada siswa, sedangkan guru pendamping berperan membantu guru kelas untuk memberikan bimbingan, informasi dan arahan kepada siswa berkategori siswa berkebutuhan khusus apabila anak tersebut tidak bisa mengikuti materi yang diberikan oleh guru kelas (guru pengajar). Ketika siswa berkebutuhan khusus tidak memahami penjelasan guru kelas, maka yang akan menjelaskan kembali materi kembali kepada siswa berkebutuhan khusus yaitu guru pendamping. Guru kelas akan bekerja sama dengan guru pendamping di dalam kelas untuk siswa berkebtuhan khusus 
Dari berbagai hal tersebut peneliti tertarik untuk meneliti interaksi anak berkebutuhan khusus di SDN 4 Kilensari kec. di kelas 1 karena di kelas ini memiliki jumlah siswa berkebutuhan khusus. Oleh karena itu penelitian ini berjudul " interaksi Sosial Siswa Berkebutuhan Khusus di SDN 4 Kilensari.

\section{METODE PENELITIAN}

Penelitian ini merupakan penelitian kualitatitf yang di laksanakan di SDN 4 Kilensari Kec. Panarukan sebagai salah satu sekolah inklusi yang ada di kabupaten Situbondo. Subjek penelitian ini yaitu kepala sekolah, guru kelas. Penelitian ini dilaksanakan mulai dari bulan januari sampai februari tahun 2020 dan sbujek penelitian ini yaitu siswa berkebutuhan khusus di kelas 1 . Teknik pengumpulan data yang digunakan yaitu metode observasi, metode wawancara, metode dokumentasi. Teknik analisinya menggunakan pengumpulan data, reduksi data, penyajian data sampai penarikan kesimpulan. Validitas data menggunkan triangulasi sumber data. Langkah- langkah Analisis data yang digunakan oleh peneliti dalam penelitian ini sebagai berikut:

1. Pengumpulan data

Untuk memperoleh informasi yang dibutuhkan, maka peneliti mengumpulkan data dengan menggunakan informasi melalui observasi, wawancara dan dokumentasi.

2. Reduksi Data

Reduksi data yaitu proses pemfokusan, penyerderhanaan dalam catatan- catatan lapangan teknis. Data yang sudah didapatkan kemudian diredukasi dengan cara mengelompookan atau memilih dan merau data yang sesuai dengan penelitian sesudah data itu terangkan kemudian disusun supaya lebih teratur.

3. Penyajian data

Penyjian data yaitu deskripsi penemuan dari apa yang diperoleh di lapangan. Penyajian data disini dibatasi sebagai sekumpulan informasi yang memberi kemungkinan adanya penarikan kesimpulan dan pengambilan suatu tindakan.

4. Penarikan kesimpulan

Pengambilan kesimpulan sangat penting untuk menegaskan pokok- pokok pemahaman dan pembahasan yang tertulis serta memaparkan ini dengan lebih komprehensif.

\section{HASIL DAN PEMBAHASAN}

Hasil temuan peneliti bahwasanya subjek yaitu anak berkebutuhan khusus downsyndrome, tuna rungu dan kesulitan belajar sama- sama memiliki kelainan berupa kesulitan untuk berkomunikasi dengan lingkungan disekitarnya namun tingkat kemampuannya berbeda- beda. Hasil penelitian terhadap subjek pertama yaitu anak down syndorme (amrul) sudah baik dengan guru, teman sekelasnya baik siswa yang berkebutuhan khusus maupun siswa reguler, meski bahasa yang digunakan oleh amrul masih kurang jelas tetapi lingkunganga masih bisa memahami. Subjek sudah bisa berinteraksi dengan baik di karenakan subjek sudah terbiasa bermain di lingkungan rumahnya. Ketika berinteraksi subjek (amrul) sangat antusias ketika orang lain mengajak 
berkomunikasi. Setiap ada orang baru yang ingin mengajak berinteraksi subjek selalu menarik perhatian dan subjek selalu memulai untuk interaksi.

Hasil penelitian terhadap subjek yang kedua yaitu anak autis (syafrika)menunjukkan bahwasanya subjek terlihat masih kurang mampu dalam berinteraksi sosial. Subjek hanya bisa berinteraksi sosiao dengan orang terdekat saja seperti keluarga dan orang yang di anggap baik. Pandangan subjek hanya datar, ketika di ajak berkomunikasi subjek akan menjawab dengan bahasa yang kurang jelas dan selalu mengeluaran kata- kata " Diam " dengan jari telunjuk yang diarahkan ke mulut subjek. subjek selalu sibuk dengan berkeliling kelas dan akan diam di kelas 5 dikarenakan subjek sangat nyaman dengan guru kelas 5. Subjek tidak pernah memulai interaksi sosial terlebih dahulu, jika ada temannya berkumpul subjek akan ikut berkumpul meski hanya sebentar.

Subjek ketiga yaitu pandji Asmoro Bangun bisa di panggil dengan "Boy", anak berkebutuhan khusus tunarungu. Subjek termasuk bisa dalam berinteraksi sosial dengan lingkungannya. subjek memiliki keinginan untuk memulai komunikasi meski bahasanya masih kurang bisa dipahami, akan tetapi boy bisa menangggapi pembicaraan dari lawan bicaranya asalkan lawan bicaranya berbicara agak keras ke telinga boy. Boy siswa berkebutuhan khsus kriteria tuna rungu yang menggunkan alat bantu dengar. Ketika jam istrihat, subjek bermain dengan teman kelasnya, meski terkadang boy tidak memahami apa dibicarakan oleh temannya.

\section{Guru Kelas dan Guru pendamping}

Guru kelas memiliki peranan penting dalam mendidik para peserta didiknya tidak terkecuali pada anak berkebutuhan khusus dalam hal ini guru kelas dan guru pendamping khusus memberikan intruksi mengenai peserta didiknya baik yang reguler maupun anak berkebutuhan khusus untuk mnenunjang mutu peserta didiknya. Baik di bidang akademik maupun non akademik. Dalam pengajaran guru kelas memberikan materi kepada peserta didik reguler dan guru pendamping akan mendampingi anak berkebutuhan khusus dalam pembelajaran maupun komunikasi. Di SDN 4 Kilensari memiliki anak berkebutuhan khusus yang duduk di kelas 1 yaitu 3 orang yaitu anak downsyndrome, autis dan tuna rungu. Mereka ditempatkan didalam kelas reguler dengan duduk berkelompok. Guru kelas dan guru pendamping memberikan stimulus kepada peserta didik berkebutuhan khusus yaitu syafrika,amrul dan boy untuk berinteraksi dengan siswa reguler. Menurut penuturan guru kelas bahwa anak berkebutuhan khusus yang ada di kelas 1 sudah bisa berinteraksi dengan baik dengan lingkungan, akan tetapi masih ada yang masih perlu di dampingin karena bahasa mereka masih kurang jelas sehingga siswa reguler sering kurang faham ketika berkomunikasi. Guru sering mengajak siswa anak berkebutuhan khusus bicara dengan cara menyampaikan pertanyaan terkait kegiatan yang sudah dilakukan oleh anak berkebutuhan khusus. Syafrika siswa berkebutuhan khusus kategori autis, anak tersebut masih kurang bisa berinteraksi dengan baik dengan lingkungannya, karna subjek sering keliling sekolah dan kalau sudah ada di kelas syafrika akan duduk 
dan akan diem ketika berada dekat dengan teman sekelasnya. Ketika diajak berkomunikasi syafrika akan menjawab "DIAM " dengan menjulurkan jari telunjuknya ke bibirnya. Syfarika tidak bisa memulai dala percakapan,akan tetapi setiap teman atau orang lain bertanya dia akan menjawab meski bahasanya kurang bisa dimengerti dengan wajah yang tidak fokus dengan lawan bicaranya.

Guru pendampingnya melatih syafrika untuk interaksi sosial dengan membiasakan untuk mengucapkan salam dan salaman ketika masuk ke dalam kelas serta mengajarkan untuk bertanya dengan mengetuk meja dengan menngunakan pensil.Berbeda dengan Amrul anak berkebutuhan khusus dari kategori Down syndrome, anakn tersebut sudah bisa berinteraksi dengan lingkungannya, amrul selalalu memulai untuk berkomunikasi dengan siapa saja meski bahasanya yang masih kurang jelas. Di dalam pemeblajaran amrul sudah bisa menerima pembelajaran meski harus di pandu dengan guru pendamping. amrul bisa membaur dengan teman kelasnya dengan bermain bersama, ketika dia mengalami kesulitan amrul akan menemui guru kelas atau guru pendampingnya. Sedangkan anak berkebutuhan khusus dengan kategori tuna rungu yaitu "boy" hampir sama dengan amrul yang sudah baik dalam berinteraksi dengan lingungan baik di dalam keas maupun luar kelas. Hal ini karena boy sudah dibiasakan untuk berinteraksi dengan keluarganya meski terkadang boy tidak bisa memahami bahasa lawan bicaranya, reaksi boy ketika tidak bisa memhami pembicaraan lawan bicaranya biasnaya temannya akan bicara sedikit keras di telingan boy. Boy anak tuna rungu yang menggunkan alat bantu dengar. Guru pendamping akan menjelaskan materi pelajaran dengan nada sedikit keras di telinga boy. Boy akan mengikuti intruksi yang diberikan oleh guru pendamping dengan baik. Setipa mengalami kesulitan boy selalu menenpuk undak atau menarik baju guru pendamping.

Guru tidak segan untuk menegur siswa reguler ketika menganggu anak berkebutuhan khusus. guru kelas dan guru pendamping sangat mengajari terhadap anka brekbetuhan khusus dalam berinteraksi dengan lingkungan agar mereka bisa membaur dengan teman- nteman reguler dengan baik. Teman sekelasnya yaitu anak reguler yang awalnya masih asing dengan kehadiran teman yang berkebutuhan khusus yang satu kelas dengannya. Mereka yang awalnya masih takut dan canggung untuk memiliki teman kelas yang berkebutuhan khusus, guru kelas memberikan pengertin dan penjelasan dengan baik dan lambat laun teman sekelasnya sudah biasa menerima dengan baik kehadiran siswa berkebutuhan khusus. berdasarkan pengamatan yang dilakukan oleh peneliti anak berkebutuhan khusus yang ada di kelas 1 sudah bisa berinteraksi dengan teman sekelasnya, ketika jam istirahat mereka bermain, bercanda bareng dengan baik. Dari anak berkebutuhan khusus yang ada di kelas 1 amrul dan boy merupakan anak berkebutuhan khusus yang sangat bagus interaksi sosialnya di bandingkan dengan syafrika. 


\section{Pembahasan}

Hal yang sangat penting bagi siswa anak berkebutuhan khusus merupakan kemampuan berinteraksi agar mereka dapat menyesuaikan diri. Setiap anak berkebutuhan khusus menunjukkan interaksi sosial yang berbeda- beda, hal ini sesuai fakta yang ada dilapangan yaitu mereka bisa berinteraksi dengan guru dan teman- temannya namun ada pula anak berkebutuhan khusus yang mengalami hambatan ketika berinteraksi dengan guru dan teman- temannya. SDN 4 Kilensari di kelas 1 memiliki siswa berkebutuhan khusus dengan berbagai kriteria yaitu syafrika (autis), Amrul (down syndrome) dan Boy (tunarungu).

Guru memiliki peranan yang sangat penting dalam dunia pendidikan. Guru juga memiliki peranannya masing- masing yang berbeda antara satu dengan yang lain terutama dalam mengembangkan kemmapuan interaksi anak berkebutuhan khusus. Apabila guru mendidik siswa dengan baik, peduli dan penuh kasih sayang maka kemampuan beerinteraksi anak berkebutuhan khusus akan optimal, namun jika guru acuh tak acuh dengan keadaan siswa maka siswa akan mengalami banyak hambatan dalam berinteraksi disekolah. Peran guru pendamping khusus sangat penting dalam mengembangkan interaksi sosial bagi anak berkebutuhan khusus. Hal ini sesuai dengan penuturan dari guru pendamping khusus bapak Ilham Bachtiar :

"Anak berkebutuhan khsuus yang ada di sekolah ini terutama kelas 1 di biasakan untuk bergaul dengan siswa reguler lainnya, sehingga siswa reguler bisa menghargai anak berkebutuhan khusus dan anak berkebutuhan khusus percaya diri dan tidak minder ketika bergaul dengan siswa reguler"

Pak Ilham menjelaskan bahwa siswa anak berkebutuhan khusus di biasakan untuk bergaul dengan siswa reguler agar mereka bisa percaya diri dan berinteraksi dengan baik dan siswa reguler bisa menerima kehadiran mereka. Keberadaan siswa berkebutuhan khusus di dalam kelas tentu memberikan suasana yang berbeda terutama pada saat pembelajaran berlangsung, respon siswa berkebutuhan khusus berbeda dengan siswa reguler. Masingmasing siswa memiliki tingkat daya nalar yang berbeda. Siswa reguler dalam kegiatan pembelajaran dapat berperan aktif, sementra siswa berkebutuhan khusus belum terlihat aktif dan masih memerlukan penekanan berulang terkait materi yang sedang dibahas oleh guru. Hal ini sesuai dengan hasil pengamatan yaitu siswa reguler menerima keberadaadn siswa berkebutuhan khusus dengan bermain bersama dan bekerjasama di dalam kelas maupun di luar kelas. Meski terkadang siswa berkebutuhan khusus terkadang menjahili siswa reguler tetapi mereka tidak membalas perilaku mereka.

Dalam meningkatkan interaksi sosial anak berkebutuhan khsus setiap masuk kelas mereka di suruh untuk mengucapkan salam dan berjabat tangan terhadap guru. Di dalam kelas anak berkebutuhan khusus dilibatkan dalam pembelajaran dengan siswa reguler, tempat duduk mereka di campur dengan siswa reguler sehingga mereka bisa berinteraksi meski mengalami mereka mengalami hambatan akan tetapi siswa reguler akan membantu anak berkebutuhan khusus sebisa yang mereka bisa lakukan. Anak berkebutuhan khusus 
yang ada dikelas 1 tidak hanya berinteraksi dengan teman sekelasnya saja akan tetapi dengan kakak kelasnya juga sehingga mengenal dan beradaptasi dengan mereka yang memiliki perbedaan dan keistimewaan dengan memperlakukan dengan baik. Ketika anak berkebutuhan khusus mengalami kesulitan dalam bermain biasanya mereka tetap asyik bermain dengan menunjukkan perilaku mereka kepada temannya. Hal ini tidak heran karena para guru melakukan education terhadap siswa berkebutuhan khusus. Sesuai dengan pendapat Al- Ghazali (2013:116) yang mengatakan bahwa guru berperan sebagai fasilitator dengan menyediakan fasilitas yang memudahkan belajar anak didik, kemudian sebagi pembimbing untuk mengarahkan anak didiknya terhadap potensinya sehingga mereka menjadi manusia dewasa yang sempurna.

Interaksi sosial merupakan salah satu aspek penting bagis siswa, termasuk bagi siswa berkebutuhan khusus. Setiap siswa hidup secara sosial di dalam suatu masyarakat, termasuk bagi siswa berkebutuhan khusus. Hal tersebut menunjukkan siswa berkebutuhan khusus juga memerlukan interaksi dengan orang lain seperti dengan teman sebaya. Guru pendamping khusus menjelaskan bahwa dalam mengembangkan kemampuan interaksi sosial siswa berkebutuhan khusus selalu melibatkan siswa dengan cara membiarkan siswa berkebutuhan khusus dengan membiarkan bermain dengan siswa reguler sehingga mereka bisa beradaptasi satu dengan lainnya hal ini sesuai dengan pendapat Al- Ghazali (2013:116) peran pendamping khusus yaitu memilih dan melibatkan teman seumur untuk kegiatan sosialisasinya.

\section{KESIMPULAN}

Interaksi sosial anak berkebutuhan khusus satu dengan yang lainnya berbeda, hal ini sesuai dengan pengamatan peneliti, subjek 1 yaitu syafrika yang masih belum bisa berinteraksi dengan teman kelasnya, masih belum bisa bermain dan belum bisa menunjukkan ekspresi yang ada di dalam dirinya, Subjek masih kesulitan dalam berkomunikasi, pandangan subjek sangat datar dan cenderung tidak merespon lawan bicara sehingga temannya enggan untuk berkomunikasi. Subjek ke 2 yaitu Amrul, subjek lebih terlihat bisa berinteraksi dengan lingkungan, meski terkadang lawan bicaranya bingung dengan bahasa yang di gunakan oleh amrul. Amrul anak yang sangat ekspresif dalam berinteraksi dengan orang lain. Amrul bisa memulai untuk berkomunikasi dengan temannya, akan tetapi teman tertentu saja yang amrul kenal. Ketika tidak mengenalnya amrul akan menepuk pundak temannya, hal ini juga di lakukan amrul terhadap orang baru. Subjek ke 3 yaitu boy, subjek ini sudah lumayan baik dalam interaksi sosialnya meski terkadang kesulitan dengan pembicaraan dari temannya, dikarenakan subjek anak berkebutuhan khusus tuna rungu. Subjek juga menggunakan alat bantu dengar. Subjek sering bermain dengan teman kelasnya yang subjek kenal saja. Setiap ada orang baru yang mengajak berkomunikasi subjek selalu memasang wajah datar dan tatapannya tidak terfokus. 
Interaksi sosial anak berkebutuhan khusus yang ada di SDN 4 kilensari sudah berjalan dengan baik meskipun teman kelasnya terkadang mengalami kesulitan dalam memahani siswa berkebutuhan khusus. Dalam berinteraksi siswa akan menepuk tubuh oarang yang akan mereka ajak berkomunikasi dan jika sudah kenal dengan namanya siswa berkebutuhan khusus akan memangil berulang - ulang. Guru pendamping akan mengarahkan siswa berkebutuhan khusus yang mengalami kesulitan dalam pembelajaran di kelas. Guru kelas dan guru pendamping selalu mengarahkan siswa reguler untuk bisa berinteraksi dengan anak berkebutuhan khusus baik dalam pembelajaran, maupun interaksi. Hal ini dikarenakan agar anak berkebutuhan khusus bisa beradaptasi dengan siswa reguler.

\section{DAFTAR RUJUKAN}

Delphie, bandhi. Pembelajaran Anak Berkebutuhan Khusus Dalam Setting Pendidikan Inklusi. Sleman: Intan Sejati klaten, 2009

Effendi, Mohammad.(2006).Pengantar Pedagogik Anak Berkebutuhan Khusus. Jakarta:Bumi Aksara

I.G.A.K. Wardani, dkk. (2008). Pengantar Pendidikan Anak Luar Biasa. Jakarta : Universitas Terbuka.

Iqbal, M.A. 2013. Konsep pemikiran Al-Ghazali tentang pendidikan. Java Star Nine

Moleong, Lexy J. 2014. Metodologi Penelitian Kualitatif. Bandung : PT.Remaja Rosdakarya Offest.

Rahayu, Raini, 'Peran Guru Dalam Mengembangkan Interaksi Sosial Anak Autis di SD Alfirdau' 2017

Rifki Yudhanto, Atik Catur Budiarti, Siany Indria L, 2019. Interaksi Sosial Siswa Difabel Dalam Sekolah Inklusi Di SMA NEGERI 8 Surakarta 